\title{
A Novel Aminothiazole Derivative Induces Apoptosis and Cell Cycle Arrest in Tumor Cells
}

\author{
Minghua Li, Changwon Oh, Jun Seok Park, and Seung Wook Ham* \\ Department of Chemistry, College of Natural Science, Chung-Ang University, Seoul 156-756, Korea \\ *E-mail:swham@cau.ac.kr \\ Received August 3, 2010, Accepted September 15, 2010
}

Key Words: Aminothiazole, Anticancer, Cell cycle, Apoptosis, p53

Cancer (also called a malignant neoplasm) is a class of diseases in which a group of cells show uncontrolled cell growth, invasion and occasionally metastasis, and is a major public health problem worldwide. Cancer is a disease of deregulated cell proliferation, due to a defect in regulating the cell cycle. It is also considered to be a disease of deregulated survival, where the continuous input of survival signals is made to suppress apoptosis. Therefore, regulation of the cell cycle and apoptosis are considered to be effective cancer therapeutic methods. ${ }^{1}$

In the course of searching for anticancer agents, we became interested in the discovery of potential anticancer agents using a cell-based high-throughput screening system with a chemical library. We reported a preparation of 2-aminothiazole derivatives $^{2-6}$ in a high-speed parallel format and found that compound H154 exhibited significant cell growth inhibition against HepG2 cells with an $\mathrm{IC}_{50}$ value of $0.040 \mu \mathrm{M}$ by the MTT assay. ${ }^{7}$

Apoptosis is important, not only for the chemotherapy of cancer cells, but also in tumor chemoresistance involving an increased threshold for cell death that would require higher doses to destroy the tumor. Therefore, to investigate whether H154-induced growth inhibition was associated with apoptosis, the cell morphology and DNA damage was examined at various concentrations and periods. As shown in Fig. 2, treatment with H154 resulted in a small number of typical apoptotic cells, namely shrunken cells with fragmented nuclei (apoptotic bodies) and clear DNA ladder formation in a dose- and time-dependent manner, indicating that the population of cells underwent apoptotic cell death.

The level of caspase- 3 expression in the cells exposed to H154 was also measured to determine if compound-induced apoptosis is associated with the activation of caspase. The western blotting data showed that the level of pro-caspase- 3 remained unchanged in the H154-treated cells. However, the levels of the active subunits of caspase expression were increased in a time dependent manner. In order to further quantify the proteolytic activity of caspase- 3 in the cells, the lysates, which were equalized for the protein from the cells treated with

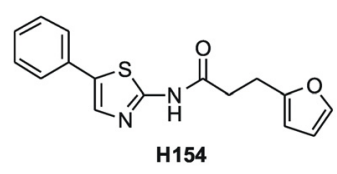

Figure 1. Chemical structure of $\mathbf{H 1 5 4}$.

H154, were assayed for their activity by quantitative detection of a fluorometric tetrapeptide substrate. As shown in Fig. 3, the caspase- 3 activity in the cells increased in a time-dependent manner.

The blockade of cell cycle progress by anti-cancer agents prevents the proliferation of cancer cells, which is also exploited for cancer therapy. To examine whether H154-induced growth inhibition was associated with cell cycle regulation, the cell cycle distribution was analyzed by flow cytometry. As illustrated in Fig. 4, $\mathrm{G}_{1}$ cell cycle arrest was observed, as indicated by the time-dependent accumulation of cells in the $\mathrm{G}_{1}$ phase. The cells treated with the compound showed 51.9\%, 64.8\%, 66.8\%, and $76.8 \%$ of cells in the $\mathrm{G}_{1}$ phase at $12,24,48$, and $72 \mathrm{~h}$, respectively, whereas the control cells treated with DMSO (the solvent in which the compound is dissolved) showed $42.7 \%$ in the $G_{1}$ phase.

(A)

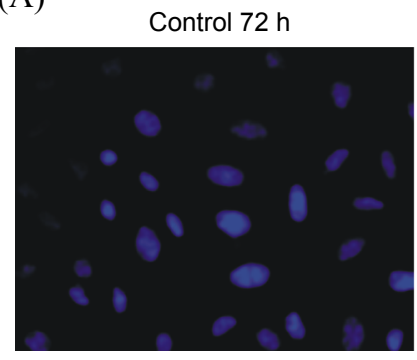

(B)
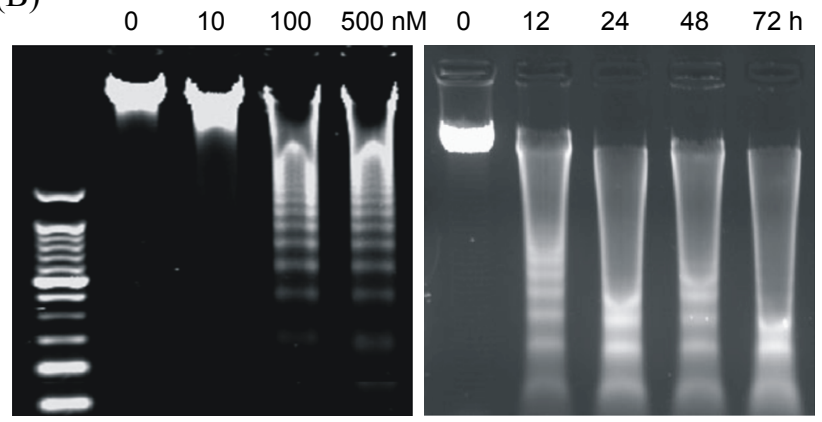

Figure 2. H154 induces apoptosis in HepG2 cells. (A) Cells treated with $100 \mathrm{nM} \mathrm{H154}$ for $72 \mathrm{~h}$ were stained with DAPI ( $10 \mathrm{ug} / \mathrm{mL}$ of PI, $100 \mathrm{ug} / \mathrm{mL}$ of Rnase A) and showed a typical apoptosis morphology. (B) Internucleosomal DNA fragmentation was examined in a timeand dose-dependent manner. The cells were treated with $100 \mathrm{nM}$ H154 for the indicated time periods. 


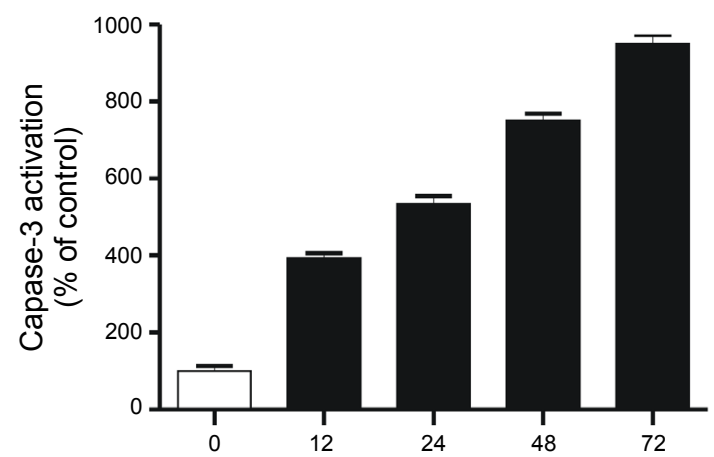

Figure 3. Caspase-3 activation is involved in $\mathbf{H 1 5 4}$ induced apoptosis. The caspase activities were assayed using Ac-DEVD-AMC as a substrate.

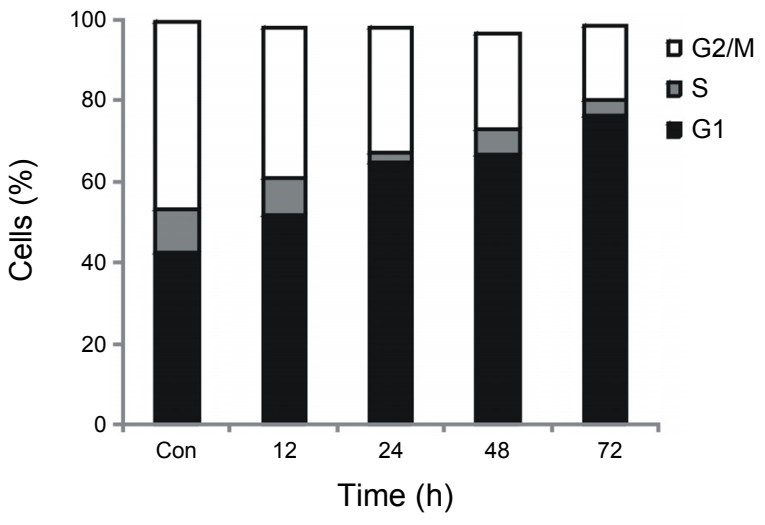

Figure 4. G1/S arrest of $\mathbf{H 1 5 4}$ treated HepG2 cells. After the H154 treatment for the indicated period, the cells were stained with PI and analyzed for the DNA content by flow cytometry at each time point.

The activation of the p53 protein as a transcription factor initiates a program of apoptosis and cell cycle arrest. ${ }^{8,9}$ A major player in $\mathrm{p} 53$-mediated $\mathrm{G}_{1}$ arrest is the $\mathrm{p} 21$ gene product that inhibits cyclin E-Cdk2. ${ }^{10}$ This cyclin-dependent kinase then acts on the $\mathrm{Rb}$ protein to depress the activity of E2F1 that promotes the transcription of genes involved in preparing a cell to progress from the $\mathrm{G}_{1}$ to $\mathrm{S}$ phase in the cell cycle. Several p53-regulated genes also enhance the secretion of cytochrome $\mathrm{c}$ into the cytoplasm from the mitochondria (bax, noxa, puma), often in a tissue-specific manner. Cytochrome $\mathrm{c}$ interacts with APAF-1 (a p53-regulated gene) to initiate a protease cascade, which leads to the activation of caspase- 9 and then caspase- 3 followed by apoptosis. ${ }^{11,12}$ This is the intrinsic apoptotic pathway that is initiated by a number of stress signals that activate the $\mathrm{p} 53$ pathway. In addition to the intrinsic pathway, p53 regulates a series of genes that initiate the dead-receptor-induced extrinsic pathway, resulting in the activation of caspase- 8 and -3 and apoptosis. ${ }^{13,14}$ Therefore, to examine that $\mathrm{p} 53$ dependent activation is involved in the apoptotic process and cell cycle arrest, the protein expression of p53 and p 21 was evaluated. As shown in Fig. 5, the amounts of the p53 and $\mathrm{p} 21$ proteins were increased by $\mathbf{H 1 5 4}$ in a time-dependent manner, suggesting that the induction of these proteins is partly essential for compound-induced cell cycle arrest and apoptosis in a p53-dependent manner. The

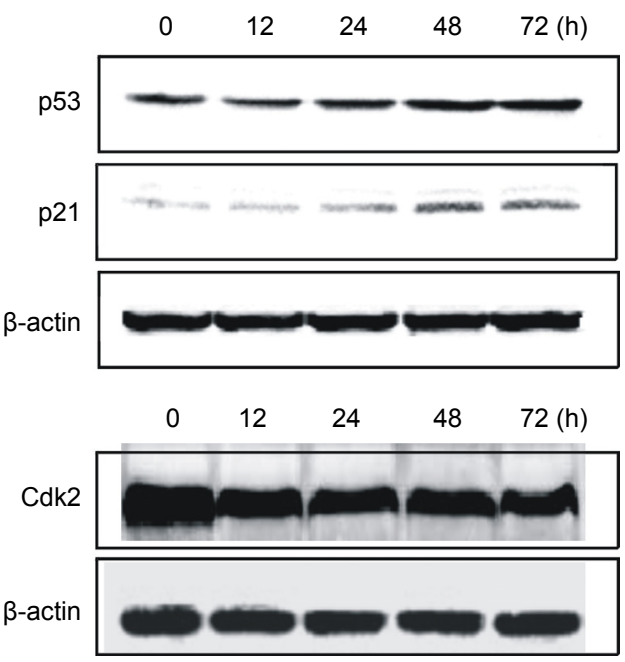

Figure 5. Protein levels of p53, p21and Cdk2 were examined by Western blot analysis at the indicated time points after a treatment with $100 \mathrm{nM} \mathbf{H 1 5 4}$.

effect of $\mathbf{H 1 5 4}$ on the level of Cdk2 protein expression, which allows the cells to transit from the $\mathrm{G}_{1}$ to $\mathrm{S}$ phase, was also investigated. However, the $\mathbf{H 1 5 4}$ treatment did not cause any change in the level of Cdk2 expression (Fig. 5).

Previous studies reported that 2-aminothiazole derivatives possess inhibitory activity against kinases, such as Cdks, by competing at the ATP binding site. ${ }^{2-6}$ It was suggested that Cdk2 controls the $\mathrm{G}_{1} / \mathrm{S}$ transition in mammalian cells. However, this compound resulted in no change in the level of $\mathrm{Cdk} 2$ expression and did not have an inhibitory efficacy for several kinases in addition to Cdk2 (data not shown). Since $\mathbf{H 1 5 4}$ has a potent antiproliferative activity and apoptosis in human hepatoma HepG2 cells, $\mathbf{H 1 5 4}$ is a promising new lead for the development of novel therapeutic agents for the treatment of cancer. Studies on the specific cellular mechanism of the action of this compound are currently underway.

\section{Experimental Section}

Cell culture. The human hepatoma HepG2 cells were obtained from the American Type Culture Collection. They were maintained in the logarithmic phase of growth in DMEM medium containing $2 \mathrm{mM}$ L-glutamine and $4.5 \mathrm{~g} / \mathrm{L}$ glucose (GIBCO BRL, Grand Island, NY) supplemented with heat inactivated $10 \%$ fetal bovine serum (GIBCO BRL), at $37^{\circ} \mathrm{C}$ in a $5 \% \mathrm{CO}_{2}$ $95 \%$ air humidified incubator.

Cytotoxicity tests of H154. The compound H154 was dissolved in DMSO and stored as aliquots at $-20^{\circ} \mathrm{C}$ until use. To assess the effect of compound on HepG2 cells, the cells $\left(2 \times 10^{4}\right.$ cells/well) were first seeded in 96-well, flat-bottomed plates in triplicate. On the next day, different concentrations of compound were added to a final volume of $200 \mu \mathrm{L}$ of growth medium/well. DMSO was then added to the control wells at equal volumes to the compound. The plates were incubated at $37^{\circ} \mathrm{C}$ in a $5 \% \mathrm{CO}_{2}$ - supplemented atmosphere for $24 \mathrm{~h}$. The medium was then removed and replaced with $150 \mu \mathrm{L}$ of $0.5 \mu \mathrm{g} / \mathrm{mL}$ of MTT (Sigma-Aldrich Chemical Co., USA) in growth medium. 
The plates were then incubated for $4 \mathrm{~h}$ at $37^{\circ} \mathrm{C}$. The reduced MTT dye was dissolved in $150 \mu \mathrm{L}$ DMSO per well. The optical density (OD) was read using an ELX800 Universal Microplate reader (Bio-Tek Co., CA, USA) at $570 \mathrm{~nm}$. The percentage inhibition was calculated as: $\%$ inhibition $=\left(1-\mathrm{OD}_{\text {test }} / \mathrm{OD}_{\text {control }}\right) \times$ $100 \%$.

DNA fragmentation analysis. Cells grown at a density of $2 \times$ $10^{6}$ cells $/ \mathrm{mL}$ in $100 \mathrm{~mm}$ dishes were exposed to the compound at various concentration and periods. The genomic DNA was prepared using a Wizard Genomic DNA Purification Kit (Promega, Madison, WI). The DNA was precipitated with isopropanol, separated in $1.5 \%$ agarose gel and visualized by UV illumination after ethidium bromide staining.

Morphological analysis. After treating the cells seeded on sterile microscope slides with the compounds, the cells were washed with PBS and fixed with paraformaldehyde for $30 \mathrm{~min}$. The cells were stained with a DAPI solution $(10 \mu \mathrm{g} / \mathrm{mL}$ of PI, $100 \mu \mathrm{g} / \mathrm{mL}$ of Rnase A) for $10 \mathrm{~min}$. The morphology of the cells was examined by Leitz phase-contrast microscopy or Zeiss live cell imaging fluorescence microscopy.

Flow cytometry analysis. Exponentially growing cells were diluted and $2 \times 10^{6}$ cells were seeded in $10 \mathrm{~mL}$ of the culture medium in $100 \mathrm{~mm}$ culture dishes. The cells were exposed to $100 \mathrm{nM}$ of the compound for various times, and centrifuged at $800 \mathrm{~g}$ for $5 \mathrm{~min}$. The pellets were mixed with a $1: 1(\mathrm{v} / \mathrm{v})$ mixture of PBS and 0.2 $\mathrm{M} \mathrm{Na}_{2} \mathrm{HPO}_{4}$ with $0.1 \mathrm{M}$ citric acid (pH 7.5), and fixed with ice-cold ethanol at $4{ }^{\circ} \mathrm{C}$ for $1 \mathrm{~h}$. The cells were washed twice with PBS and resuspended in $1 \mathrm{~mL}$ of a staining solution containing $50 \mu \mathrm{g} / \mathrm{mL}$ PI with $100 \mu \mathrm{g} / \mathrm{mL}$ DNase-free RNase A. The cell suspensions were incubated at room temperature for $1 \mathrm{~h}$, and 10,000 cells were analyzed on a FACScalibur flow cytometer (Becton-Dickinson).

Westem blot analysis. The cells were solubilized in a suspension of aPRO-PREP ${ }^{\mathrm{TM}}$ protein extraction solution (Intron Biotechnoly Inc, Korea), and incubated on ice for $1 \mathrm{~h}$. The cell lysates were centrifuged and the protein content was determined using a commercially available kit (BioRad, Mississauga, Canada). After SDS-polyacrylamide gel electrophoresis, $75 \mu \mathrm{g}$ of the proteins were transferred to an immobilon nitrocellulose membrane (Millipore) at $200 \mathrm{~mA}$ for $3 \mathrm{~h}$ at $4{ }^{\circ} \mathrm{C}$. The blots were probed with polyclonal rabbit $\mathrm{p} 53$, polyclonal mouse $\mathrm{p} 21$, betaactin antibodies (Cell Signalling Tech., Beverly, MA) and polyclonal rabbit Cdk2 (Santa Cruz, CA). The immune complexes were detected using the anti-mouse or anti-rabbit peroxidaseconjugated secondary immunoglobulin $\mathrm{G}$ antibody (Boehouringer Mannheim, Mannheim, Germany) and visualized using Electrochemiluminescence Western Blotting Detection Reagents (Amersham, Piscataway, NJ).

Caspase activity assay. The caspase- 3 activity was estimated from the liberation of fluorescent AMC after degrading the peptide substrate (Ac-DEVD-AMC) specific to caspase-3. The substrate was added to the cell lysates in an assay buffer $(50 \mathrm{mM}$ HEPES, $100 \mathrm{mM} \mathrm{NaCl}, 0.1 \%$ CHAPS, $10 \mathrm{mM}$ dithiothoureitol,
$1 \mathrm{mM}$ EDTA, $10 \%$ glycerol, $\mathrm{pH}$ 7.4) and incubated for $3 \mathrm{~h}$ at $37{ }^{\circ} \mathrm{C}$. Cleavage of the peptide substrate was monitored with excitation and emission at $380 \mathrm{~nm}$ and $460 \mathrm{~nm}$, respectively. The results are expressed as the percentage change in activity compared to the untreated control.

Statistical analysis. All values are expressed as the mean \pm S.D. compared to the controls. Significant differences were estimated using a Student's t-test. Statistical significance was set to $\mathrm{P}<0.05$. A statistics software program Graphpad prism 5.1 (Graphpad software, Inc, USA) was used for data analysis.

Acknowledgments. This work was supported by Basic Science Research Program through the National Research Foundation of Korea(NRF) funded by the Ministry of Education, Science and Technology(2010-0008375).

\section{References}

1. Blank, M.; Shiloh, Y. Cell Cycle 2007, 6, 686.

2. Kim, K. S.; Kimball, S. D.; Misra, R. N.; Rawlins, D. B.; Hunt, J. T.; Xiao, H. Y.; Lu, S.; Qian, L.; Han, W. C.; Shan, W.; Mitt, T.; Cai, Z. W.; Poss, M. A.; Zhu, H.; Sack, J. S.; Tokarski, J. S.; Chang, C. Y.; Pavletich, N.; Kamath, A.; Humphreys, W. G.; Marathe, P.; Bursuker, I.; Kellar, K. A.; Roongta, U.; Batorsky, R.; Mulheron, J. G.; Bol, D.; Fairchild, C. R.; Lee, F. Y.; Webster, K. R. J. Med. Chem. 2002, 45, 3905.

3. Misra, R. N.; Xiao, H. Y.; Kim, K. S.; Lu, S.; Han, W. C.; Barbosa, S. A.; Hunt, J. T.; Rawlins, D. B.; Shan, W.; Ahmed, S. Z.; Qian, L.; Chen, B. C.; Zhao, R.; Bednarz, M. S.; Kellar, K. A.; Mulheron, J. G.; Batorsky, R.; Roongta, U.; Kamath, A.; Marathe, P.; Ranadive, S. A.; Sack, J. S.; Tokarski, J. S.; Pavletich, N. P.; Lee, F. Y.; Webster, K. R.; Kimball, S. D. J. Med. Chem. 2004, 47, 1719.

4. Jung, F. H.; Pasquet, G.; Lambert-van der Brempt, C.; Lohmann, J. J.; Warin, N.; Renaud, F.; Germain, H.; De Savi, C.; Roberts, N.; Johnson, T.; Dousson, C.; Hill, G. B.; Mortlock, A. A.; Heron, N.; Wilkinson, R. W.; Wedge, S. R.; Heaton, S. P.; Odedra, R.; Keen, N. J.; Green, S.; Brown, E.; Thompson, K.; Brightwell, S. J. Med. Chem. 2006, 49, 955.

5. Borzilleri, R. M.; Bhide, R. S.; Barrish, J. C.; D'Arienzo, C. J.; Derbin, G. M.; Fargnoli, J.; Hunt, J. T.; Jeyaseelan, R. Sr.; Kamath, A.; Kukral, D. W.; Marathe, P.; Mortillo, S.; Qian, L.; Tokarski, J. S.; Wautlet, B. S.; Zheng, X.; Lombardo, L. J. J. Med. Chem. 2006, 49, 3766.

6. Kuramoto, M.; Sakata, Y.; Terai, K.; Kawasaki, I.; Kunitomo, J.; Ohishi, T.; Yokomizo, T.; Takeda, S.; Tanaka, S.; Ohishi, Y. Org. Biomol. Chem. 2008, 6, 2772.

7. Li, M.; Sim, Y.; Ham, S. W. Bull. Korean Chem. Soc. 2010, 31, 1463.

8. Wang, Z.; Sun, Y. Transl. Oncol. 2010, 3, 1.

9. Harris, S. L.; Levine, A. J. Oncogene 2005, 24, 2899.

10. Bartek, J.; Bartkova, J.; Lukas, J. Ann. N. Y. Acad. Sci. 1977, 284, 139.

11. Kroemer, G.; Reed, J. C. Nat. Med. 2000, 6, 513.

12. Spierings, D.; McStay, G.; Saleh, M.; Bender, C.; Chipuk, J.; Maurer, U.; Green, D. R. Science 2005, 310, 66.

13. Zhang, H.; Xu, Q.; Krajewski, S.; Krajewska, M.; Xie, Z.; Fuess, S.; Kitada, S.; Pawlowski, K.; Godzik, A.; Reed, J. C. Proc. Natl. Acad. Sci. USA 2000, 97, 2597.

14. Juin, P.; Cartron, P. F.; Vallette, F. M. Cell Cycle 2005, 4, 637. 